Article

\title{
Applicability of Concrete-Steel Composite Piles for Offshore Wind Foundations
}

\author{
Yunsup Shin ${ }^{1}$, Thomas Langford ${ }^{2}$, Kyunghwan $\mathrm{Cho}^{3}$, Jongheon Park ${ }^{3}$ and Junyoung Ko ${ }^{4, * \mathbb{D}}$ \\ 1 Offshore Geohazards and Dynamics, Norwegian Geotechnical Institute, 0855 Oslo, Norway; \\ yunsup.shin@ngi.no \\ 2 Offshore Energy, Norwegian Geotechnical Institute, 0855 Oslo, Norway; thomas.langford@ngi.no \\ 3 Civil and Offshore Team, GS E\&C, Seoul 03159, Korea; khcho2@gsconst.co.kr (K.C.); \\ parkjh1@gsconst.co.kr (J.P.) \\ 4 Department of Civil Engineering, Chungnam National University, Daejeon 34134, Korea \\ * Correspondence: jyko@cnu.ac.kr; Tel.: +82-42-821-5679
}

Citation: Shin, Y.; Langford, T.; Cho, K.; Park, J.; Ko, J. Applicability of Concrete-Steel Composite Piles for Offshore Wind Foundations. Energies 2021, 14, 4794. https://doi.org/ $10.3390 /$ en14164794

Academic Editor: Puyang Zhang

Received: 24 June 2021

Accepted: 1 August 2021

Published: 6 August 2021

Publisher's Note: MDPI stays neutra with regard to jurisdictional claims in published maps and institutional affiliations.

Copyright: (c) 2021 by the authors. Licensee MDPI, Basel, Switzerland. This article is an open access article distributed under the terms and conditions of the Creative Commons Attribution (CC BY) license (https:// creativecommons.org/licenses/by/ $4.0 /)$.

\begin{abstract}
Offshore wind-turbine support structures are largely made of steel since steel monopiles have accounted for the majority of installations in the last decade. As turbines become bigger, steel structures have led to an exponential increase in material and installation costs. From this point of view, the use of concrete for future support structures has been initiated. In this study, concrete-steel composite piles have been investigated. A pre-tensioned high strength concrete pile was placed in the lower part, mainly to support the axial load, and a steel pile in the upper part to resist the lateral load. A mechanical joint was adapted to connect the two different types of piles. Static axial, dynamic axial, and lateral load tests were performed to evaluate the load-displacement response of the composite pile, verify the integrity of the mechanical joint, and investigate its potential application to offshore wind foundations. This paper focused on the load-displacement response and the connection integrity; in particular, it investigated the lateral load-displacement response by comparing it to the results of beam-spring analysis. Based on the results from the field tests, a site-specific lateral load-displacement curve was suggested, and the connection integrity was verified.
\end{abstract}

Keywords: composite pile; mechanical joint; axial pile load test; lateral pile load test; load-displacement response; connection integrity

\section{Introduction}

The monopile is the dominant foundation system for current and planned offshore wind farm developments in shallow coastal waters, particularly in Europe [1]. The main reason for its predominance is a straightforward design and relatively simple installation and transportation processes. Recently, they have been used on wind farms for wind turbines larger than $8 \mathrm{MW}$ located in water more than $30 \mathrm{~m}$ deep. Such large monopiles have led to an exponential increase in material and installation costs [2].

In recent years, multi-leg substructures for offshore wind turbines have been used, especially in Asia. They have three or four legs, and each is anchored by means of a pile. Similar structures have been used in the oil and gas industry for several decades $[3,4]$. Tripod substructures consist of a three-leg truss structure supporting tubular steel foundations. Steel tripods were used on the German wind farms Alpha Ventus, Trianel Windpark Borkum I and Global Tech I, to support $5 \mathrm{MW}$ turbines at water depths of $27-41 \mathrm{~m}$ and at distances of $45-110 \mathrm{~km}$ from the coast $[5,6]$.

These offshore wind turbine support structures are predominantly made of steel since steel monopiles account for the vast majority of installations in the last decade and new types of multi-leg steel structures have been developed in recent years. However, as wind turbines become larger, and potential sites for offshore wind farms are located in ever deeper waters, the conditions for the design, transport, and installation of support 
structures are changing. From this point of view, the use of concrete for future offshore turbine support structures has started. Recent advances and technologies still under development have been reviewed, and it was found that these new developments meet the challenges associated with concrete support structures, allow production costs to be lowered and facilitate transport and installation [7].

To evaluate the advantages of concrete, a composite pile foundation composed of a pre-tensioned high strength concrete pile (PHC pile) and a regular steel tube pile was used in an onshore engineering practice [8,9]. In the study, "hybrid substructure system for offshore wind turbines", the main substructure was a tripod jacket structure system made of cylindrical steel piles connected to pre-installed concrete pile foundations at water depths of 20-30 m [10]. Improvements in the lateral capacity of a large diameter monopile in dense sand was investigated in combination with the reinforced concrete footings [11]. A structural analysis was performed to evaluate the adequacy of the behavior mechanism of a $3 \mathrm{MW}$-class piled concrete foundation in Offshore, Korea [12]. However, those concrete foundations were not applied on actual sites because of a lack of information on structural behavior and the proper foundation design methods.

In this study, a potential application for concrete-steel composite pile foundations (upper steel piles and lower concrete piles) was investigated by field pile load test data. Field pile load tests include static axial, dynamic axials, and lateral load tests to evaluate the load-displacement response of the concrete-steel composite pile, verify the integrity of the mechanical join, and investigate the potential application to the offshore wind foundations.

Figure 1 shows a potential application for the offshore wind foundations: a concept design of a tripod jacket structure system and a monopile with composite pile foundations. The cost of the pile can be saved by using concrete instead of steel, but there is lack of knowledge about composite piles in offshore structures and no well-proven design and installation methods.
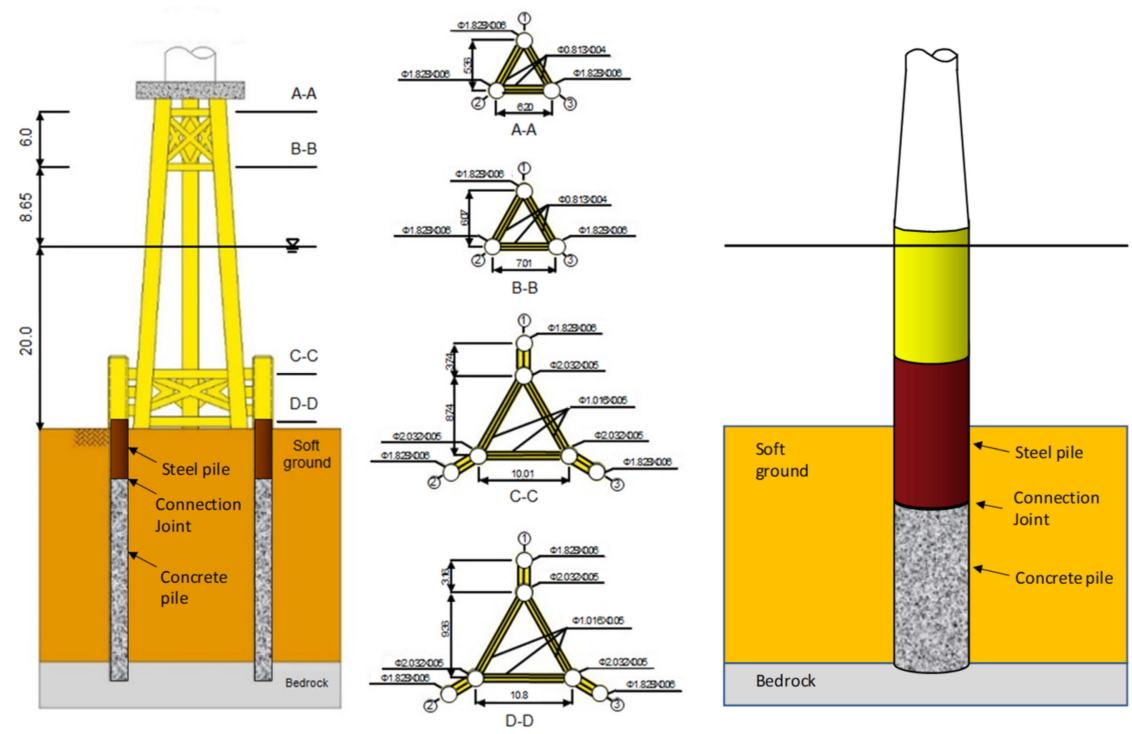

Figure 1. Concept design of a tripod jacket structure system and monopile with composite pile foundations.

The overall objective of this study was to investigate the behavior of concrete-steel composite pile foundations by field pile load tests: three dynamic axial load tests, one static axial load test, and five lateral load tests for three small-sized piles with a diameter of $500 \mathrm{~mm}$ and four large-sized piles with a diameter of $1000 \mathrm{~mm}$ to verify the possible application to offshore wind foundations. The axial and lateral load-displacement responses of the composite piles were observed by field pile load tests and the lateral behavior was compared to the results of a beam-spring analysis. Based on those results, the site-specific 
lateral load-displacement $(p-y)$ curve was proposed, and pile integrity was verified for a practical design approach.

\section{Design and Installation of Concrete-Steel Pile}

\subsection{Design Method}

There are two generally proven approaches to estimating the allowable deflection of a lateral loaded pile: in the first, the subgrade-reaction approach, the continuous nature of the soil medium is ignored and the pile reaction at a point is simply related to the deflection at that point [13], and in the second, the elastic approach, the soil is assumed to be an ideal elastic continuum [14]. For better estimations of complicated pile behavior, non-linear characteristics should be considered. The relationship between pressure and deflection at any point along a pile is nonlinear, and several approaches have been developed to account for this nonlinearity. The most widely employed approach appears to be the so-called " $p-y$ curve", developed by Reese [15]. In this method, a finite-difference solution is obtained to the following equation.

$$
\frac{d^{2} M}{d z^{2}}+\left(P_{z}\right) \frac{d^{2} \rho}{d z^{2}}-p=0
$$

where, $\rho$ is deflection; $M$ is moment; $z$ is depth; $P_{z}$ is axial load on pile at depth $z$; and $p$ is soil-reaction per unit length. When it comes to the composite piles, this $p-y$ curve was used to analyze pile behavior and determine the upper steel pile length for the composite piles [13]. By this method, the upper pile length was decided by calculating the depth at which $50 \%$ of the maximum bi-directional moments took place. With this calculated depth, $\alpha$ depth, which can be $1.0 \mathrm{~m}$, would be added as a safety margin shown Figure 2.

\section{Bending Moment $(\mathrm{kN} \cdot \mathrm{m})$, Shear Force $(\mathrm{kN})$}

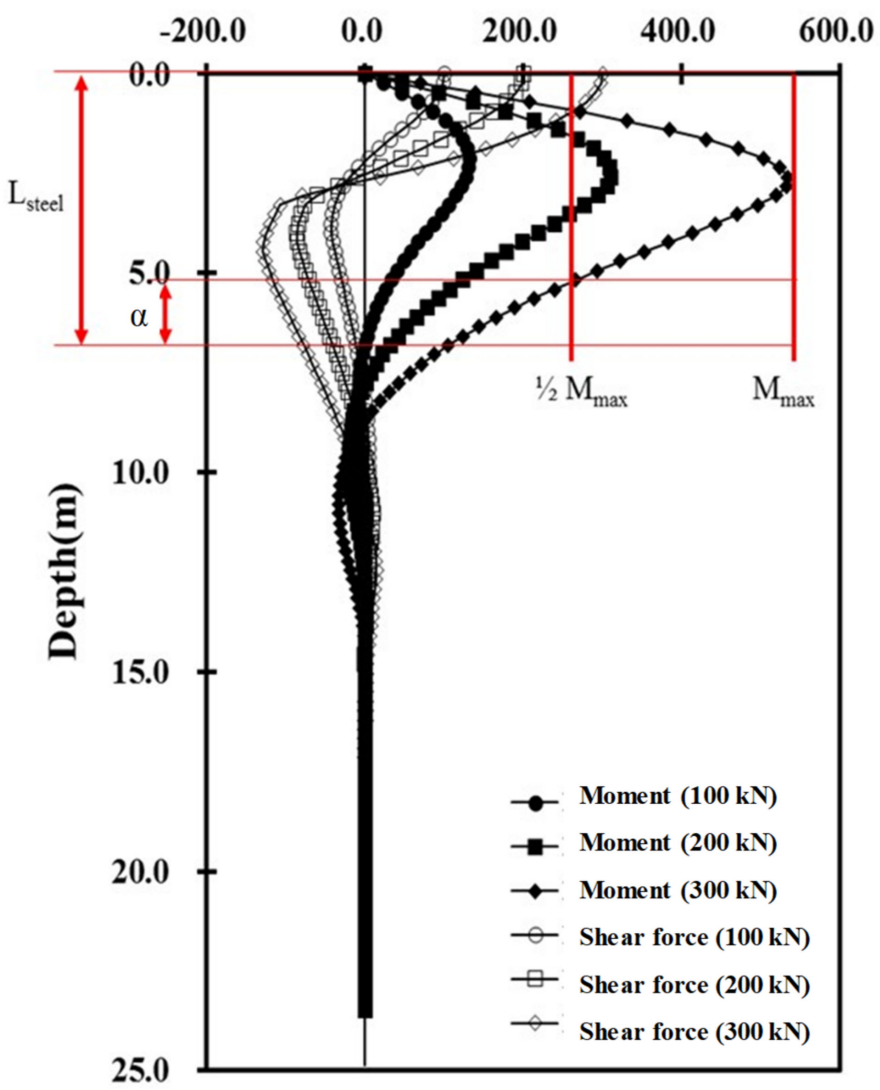

Figure 2. Determination of upper steel pile length for composite pile . 


$$
L_{\text {steel }}=L_{\frac{1}{2} M_{\max }}+\alpha(\mathrm{m})
$$

where, $L_{\text {steel }}$ is the minimum of upper steel pile length, and $L_{(1 / 2) \text { Mmax }}$ is the depth at which the maximum moment is imposed on the pile under the lateral loads.

For offshore wind structures, the upper part of the pile is subjected to large horizontal loads and overturning moments, which gradually decrease along the pile and almost end up at zero. From the certain depth under the ground, the overturning moments and shear stresses have little effect on the behavior of the pile but the axial stresses are the main governing factors for pile foundation design. Table 1 shows the material properties of steel pile and PHC pile for composite pile design.

Table 1. Material properties of steel pile and PHC pile.

\begin{tabular}{|c|c|c|c|c|c|c|c|}
\hline Pile Type & $\begin{array}{l}\text { Diameter } \\
(\mathrm{mm})\end{array}$ & $\begin{array}{l}\text { Thickness } \\
\text { (mm) }\end{array}$ & $\begin{array}{l}\text { Section Area } \\
\left(\mathrm{mm}^{2}\right)\end{array}$ & $\begin{array}{l}\text { Elastic Modulus } \\
\text { (MPa) }\end{array}$ & $\begin{array}{c}\text { Yielding } \\
\text { Stress (MPa) }\end{array}$ & $\begin{array}{c}\text { Allowable } \\
\text { Stress (MPa) }\end{array}$ & Material \\
\hline Steel pile & 500 & 12 & 18,400 & 210,000 & 240 & 140 & SPS 400 \\
\hline PHC pile & 500 & 80 & 105,600 & 40,000 & 80 & 20 & Type-A \\
\hline
\end{tabular}

\subsection{Installation Methods}

Figure 3 shows the installation methods for composite piles applied in the field in this study. Two methods were applied: (1) Pile driving, and (2) Augering and water jetting. The pile-driving method was used for D500 $\mathrm{mm}$ piles and the augering for the D1000 $\mathrm{mm}$ piles. It was known that piles installed by driving are inclined to have higher shaft friction than those installed by augering and water jetting due to the undisturbed zone along the pile during installation. For the pile driving method, the hydraulic (type DH685) with $160 \mathrm{kN}$ weight hammer was used (Figure 3a). For the augering method, a crane (type DH900) and auger with an extended bit (diameter of 950 to $1050 \mathrm{~mm}$ ) air nozzles for water jetting was used. The pile was placed on the ground and the auger inserted through the steel and concrete pile (Figure $3 b$ ) The ground is disturbed by augering and water jetting (Figure 3c). Then, the pile is penetrated by its self-weight. The installation of the composite piles was verified by both methods, which can be applied to the offshore substructures. Precast concrete piles, steel piles, and joint connections can be transported by an offshore vessel.

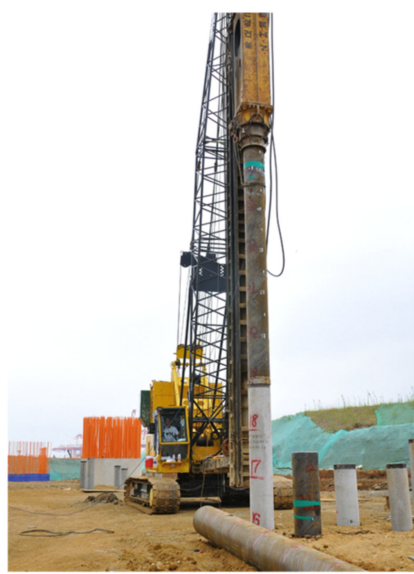

(a)

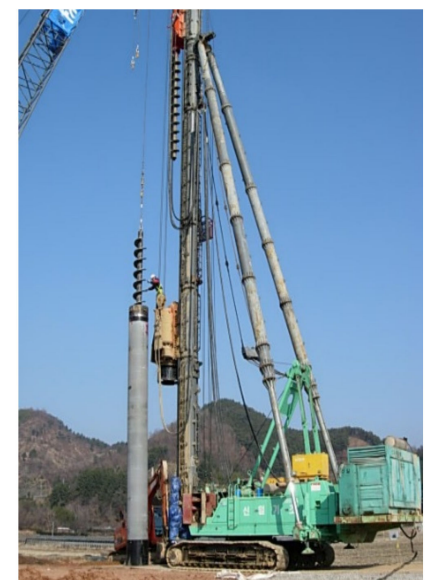

(b)

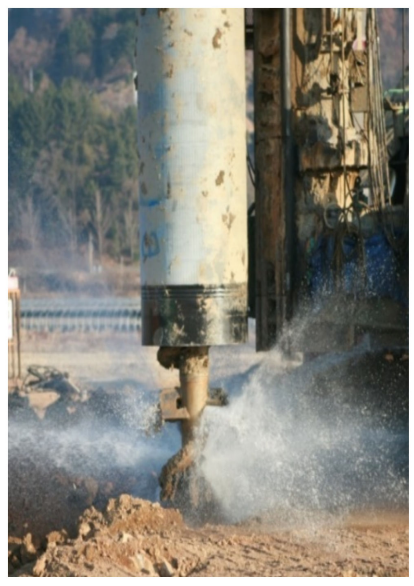

(c)

Figure 3. Pile installation methods for composite piles applied in the field: (a) Pile driving method; (b) Auger inserted through the pile; (c) Auger bit and water jetting.

In this study, the axial and lateral load-displacement responses of a composite pile was observed by field pile load tests and the lateral load-displacement is compared to the results from beam-spring analysis. Based on those results, the site-specific lateral 
load-displacement $(p-y)$ curve was proposed, and pile integrity was investigated with a practical design approach.

\subsection{Joint Integrity}

Regarding to the moments and stresses distribution, composite pile foundations were suggested to endure large overturning moments in the upper, steel-tube part of the pile and large axial loads in the lower, pre-stressed concrete part. The key issue for the application of a hybrid pile foundation is a connection method between the two different types of piles. The methods used with composite piles can be classified into two categories: welding and non-welding. In general, steel-tube and concrete composite piles are connected by welding [8]. On the other hand, a non-welding method, i.e., a mechanical joint, can combine two piles with a specially designed device as presented in Figure 4 [9].
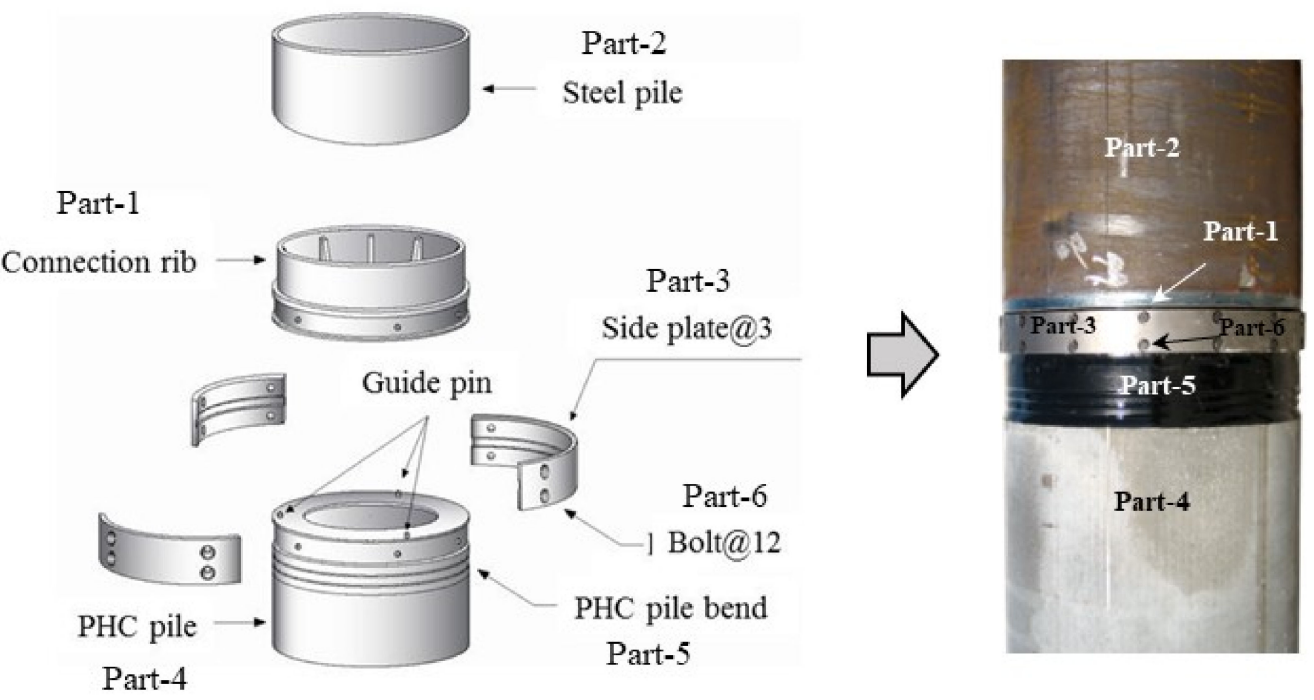

Figure 4. Mechanical jointed composite pile foundation with a steel pile and a concrete pile.

The mechanical joint uses a three-piece side-connecting panel and several bolts fitting the upper pile end to the lower pile top. In such a mechanism, the overturning moments and shear stresses from the upper part of the pile are transferred to the lower part of pile with the side connecting panel at the joint. There are several advantages to the mechanical joint: consistent quality and easy installation and maintenance. It can increase constructability regardless of weather conditions and economic cost, especially for large-diameter piles. A few studies and tests have been done on the non-welding mechanical joint method. The integrity of a joint was tested and verified by a three-point bending tests (Figure 5) and numerical analysis. According to the previous study, no damage occurred until the tensile cracks in PHC pile were generate at the load of $140 \mathrm{kN}$ [9]. In the case of steel elements, such as parts $1,2,3,5$, and 6 , the maximum lateral resistances tend to increase along with the maximum axial resistance but then start to decrease beyond a certain point of axial resistance. However, in the case of concrete elements, such as part 4, the maximum lateral resistance tended to decrease as the axial resistance increased.

Even though this study was verified by onshore pile load tests, more verification will need to be done before expanding the application to the offshore pile foundations. Table 2 shows material properties of each part of mechanical joint. 

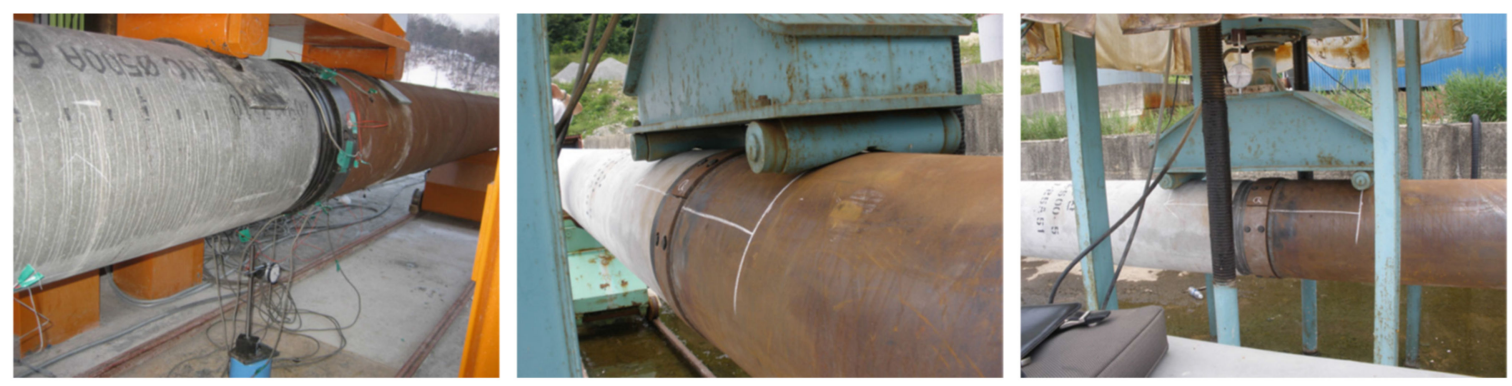

Figure 5. Three-point bending test of mechanical joint of a steel pile and a concrete pile [9].

Table 2. Material properties of mechanical joint.

\begin{tabular}{|c|c|c|c|c|c|c|c|}
\hline \multicolumn{2}{|c|}{ Mechanical Joint } & \multirow{2}{*}{ Material } & \multirow{2}{*}{ Size (mm) } & \multirow{2}{*}{$\begin{array}{l}\text { Elastic Modulus } \\
\text { (MPa) }\end{array}$} & \multirow{2}{*}{$\begin{array}{c}\text { Yielding } \\
\text { Stress (MPa) }\end{array}$} & \multirow{2}{*}{$\begin{array}{l}\text { Allowable } \\
\text { Stress (MPa) }\end{array}$} & \multirow{2}{*}{$\begin{array}{c}10 \% \text { Increased } \\
\text { Allowable } \\
\text { Stress (MPa) }\end{array}$} \\
\hline Part & Name & & & & & & \\
\hline Part 1 & N.C.P. Joint & SC450 & - & 210,000 & 240 & 140 & 154 \\
\hline Part 2 & PHC bend & SC450 & - & 210,000 & 240 & 140 & 154 \\
\hline Part 3 & Side plate & SS400 & $14 \mathrm{t}$ & 210,000 & 240 & 140 & 154 \\
\hline Part 4 & PHC pile & $f_{c k}=80 \mathrm{MPa}$ & A-Type & 35,000 & 80 & 20 & 22 \\
\hline Part 5 & Steel pile & SS400 & $500 \times 12 t$ & 210,000 & 240 & 140 & 154 \\
\hline Part 6 & Bolts & SCR420B & $\mathrm{M} 14 \times 25$ & 210,000 & 900 & 530 & 583 \\
\hline
\end{tabular}

\section{Field Pile Load Tests}

\subsection{Soil Stratigraphy}

The site investigations were carried out at two test sites (site A and site B) to establish soil-design parameters required for the lateral behavior of composite piles and structural integrity of the connect joint. For the site investigations at the two test sites, the upper soft, silty clay was found overlaying a very soft clay. The soil profile could be classified to three soil units, which are herein called unit I, II and III. Both units I and II consisted of a soft, silty olive-grey clay with a very consistent undrained shear strength increase with depth. Unit III was weathered rock. Two SPT tests were carried out at the test sites and one down-hole CPTU to a depth of approximately $25 \mathrm{~m}$ was performed at Site B. Table 3 presents a summary of the soil layering and representative soil parameters for the two test sites.

Table 3. Soil units and representative soil parameters at the site A and site B.

\begin{tabular}{|c|c|c|c|c|c|c|c|c|}
\hline Site & Layer & $\begin{array}{c}\text { Average } \\
\text { Depth Below } \\
\text { Seafloor, m }\end{array}$ & $\begin{array}{c}\text { Water } \\
\text { Content, w\% }\end{array}$ & $\begin{array}{l}\text { Total Unit } \\
\text { Weight, } \gamma \text {, } \\
\mathrm{kN} / \mathrm{m}^{3}\end{array}$ & $\begin{array}{c}\text { Plasticity } \\
\text { Index, } \\
I_{p}, \%\end{array}$ & $\begin{array}{c}\text { Undrained } \\
\text { Shear Strength, } \\
s_{u}, \mathrm{kPa}\end{array}$ & $\begin{array}{l}\text { SPT } n \\
\text { Value }\end{array}$ & $q_{u}(\mathrm{MPa})$ \\
\hline \multirow{3}{*}{ Site A } & Unit I & $0-3$ & 48 & 18 & 20 & $70-80$ & 9 & - \\
\hline & Unit II & $3-25$ & 50.4 & 18 & 27.5 & $30-70$ & $3-6$ & - \\
\hline & Unit III & $25-$ & - & - & - & - & over 30 & - \\
\hline \multirow{3}{*}{ Site B } & Unit I & $0-3$ & 50 & 18 & 21 & $20-30$ & 4 & 0.4 \\
\hline & Unit II & $3-35$ & 52 & 18 & 28 & $20-80$ & $3-7$ & $0.4-1.1$ \\
\hline & Unit III & $35-$ & - & - & - & - & over 30 & - \\
\hline
\end{tabular}

\subsection{Test Pile Geometery}

Lateral and dynamic/static axial pile load tests on the composite piles and pre-stressed concrete piles were carried out to analyze the drivability of the piles, calculate the lateral/axial bearing capacities, interpret lateral behavior, and assess the structural safety of mechanical joints. Type- 1 is a small-sized and Type- 2 is a large-sized pile with diameters of $500 \mathrm{~mm}$ and $1000 \mathrm{~mm}$, respectively. The test pile length with the ratio of upper steel pile and types of pile load tests are shown in Table 4. 
Table 4. Test pile geometries and length ratio of the upper steel pile for pile load tests.

\begin{tabular}{|c|c|c|c|c|c|c|c|c|c|c|c|}
\hline \multirow[b]{2}{*}{ Cas } & & \multirow{2}{*}{$\begin{array}{c}\text { Types of } \\
\text { Composite Pile } \\
\text { Foundations }\end{array}$} & \multirow{2}{*}{$\underset{(\mathrm{mm})}{\text { Diameter }}$} & \multirow{2}{*}{$\begin{array}{l}\text { Length of } \\
\text { Upper } \\
\text { Steel } \\
\text { Pile (m) } \\
\end{array}$} & \multirow{2}{*}{ 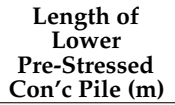 } & \multirow{2}{*}{$\begin{array}{l}\text { Total } \\
\text { Pile } \\
\text { Length } \\
\text { (m) }\end{array}$} & \multirow{2}{*}{$\begin{array}{c}\text { Ratio of } \\
\text { Upper } \\
\text { Steel Pile } \\
(\%)^{*}\end{array}$} & \multicolumn{3}{|c|}{ Types of Pile Load Tests } & \multirow{2}{*}{$\begin{array}{l}\text { Installation } \\
\text { Methods }\end{array}$} \\
\hline & & & & & & & & $\begin{array}{c}\text { Dynamic } \\
\text { Axial }\end{array}$ & $\begin{array}{l}\text { Static } \\
\text { Axial }\end{array}$ & $\begin{array}{c}\text { Static } \\
\text { Lateral }\end{array}$ & \\
\hline $\begin{array}{l}\text { Type-1 } \\
500 \mathrm{~mm}\end{array}$ & Pile-1 & $\begin{array}{l}\text { Steel pile }\left(12 t^{* *}\right) \\
+ \text { Pre-stressed } \\
\text { concrete }(80 t)\end{array}$ & 500 & 4.4 & 18 & 22.4 & $20 \%$ & & & $\sqrt{ }$ & Driving \\
\hline $\begin{array}{l}\text { compos- } \\
\text { ite pile } \\
\text { (Site A) }\end{array}$ & Pile-2 & $\begin{array}{l}\text { Steel pile }(12 t)+ \\
\text { Pre-stressed } \\
\text { concrete }(80 t)\end{array}$ & 500 & 5.0 & 14 & 19 & $26 \%$ & & & $\sqrt{ }$ & Driving \\
\hline \multirow{5}{*}{$\begin{array}{c}\text { Type-2 } \\
1000 \mathrm{~mm} \\
\text { compos- } \\
\text { ite pile } \\
\text { and Pre- } \\
\text { stressed } \\
\text { concrete } \\
\text { pile } \\
\text { (Site B) }\end{array}$} & Pile-3 & $\begin{array}{l}\text { Steel pile }(12 t)+ \\
\text { Pre-stressed } \\
\text { concrete }(80 t)\end{array}$ & 500 & 10.5 & 13 & 23.5 & $45 \%$ & & & $\sqrt{ }$ & $\begin{array}{c}\text { Augering + } \\
\text { water } \\
\text { jetting }\end{array}$ \\
\hline & Pile-4 & $\begin{array}{l}\text { Steel pile }(16 t)+ \\
\text { Pre-stressed } \\
\text { concrete }(130 t)\end{array}$ & 1000 & 8.0 & 25 & 33 & $24 \%$ & $\sqrt{ }$ & & $\sqrt{ }$ & $\begin{array}{c}\text { Augering + } \\
\text { water } \\
\text { jetting }\end{array}$ \\
\hline & Pile-5 & $\begin{array}{c}\text { Pre-stressed } \\
\text { concrete }(130 \mathrm{t})\end{array}$ & 1000 & 0.0 & 29 & 29 & $0 \%$ & $\sqrt{ }$ & \multirow{3}{*}{$\sqrt{ }$} & \multirow[t]{3}{*}{$\sqrt{ }$} & $\begin{array}{c}\text { Augering + } \\
\text { water } \\
\text { jetting }\end{array}$ \\
\hline & Pile-6 & $\begin{array}{l}\text { Steel pile }(16 t) \\
\text { + Pre-stressed } \\
\text { concrete }(130 t)\end{array}$ & 1000 & 15.0 & 25 & 38 & $40 \%$ & & & & $\begin{array}{c}\text { Augering + } \\
\text { water } \\
\text { jetting }\end{array}$ \\
\hline & Pile-7 & $\begin{array}{l}\text { Pre-stressed } \\
\text { concrete }(130 \mathrm{t})\end{array}$ & 1000 & 0.0 & 37.5 & 37.5 & $0 \%$ & $\sqrt{ }$ & & & Driving \\
\hline
\end{tabular}

${ }^{*}$ ratio of upper steel pile $(\%)=$ length of upper steel pile/total pile length, ${ }^{* *} 12 \mathrm{t}=$ pile thickness of $12 \mathrm{~mm}$.

\subsection{Axial Pile Load Tests}

Three dynamic axial pile load tests used a hydraulic hammer $(160 \mathrm{kN})$ and manipulated the stroke between 0.5 and $1.5 \mathrm{~m}$. One static axial pile load test was conducted using the reaction of earth anchors (16 units) embedded into weathered rocks and conducted according to 4-cycle repeated load test procedure suggested by ASTM D 1143 [16] with the maximum test load of up to $12,000 \mathrm{kN}$ in Figure 6a. Different pile installation methods (driving and augering with water jetting) were implemented to compare and examine differences between bearing capacities of each construction method.

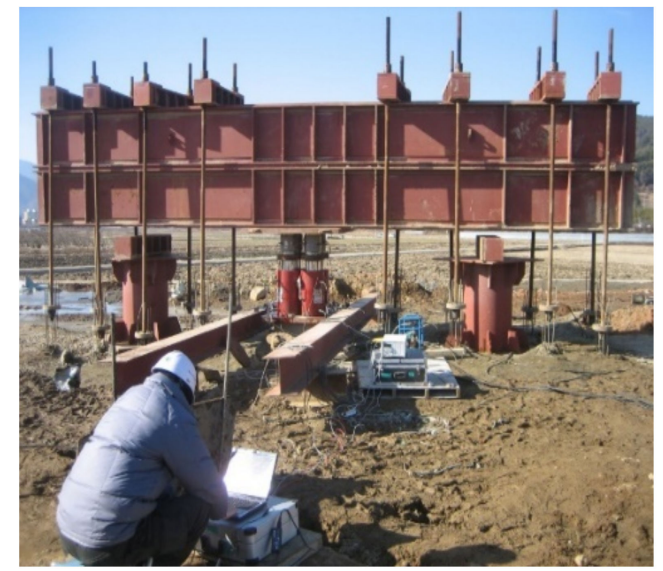

(a)

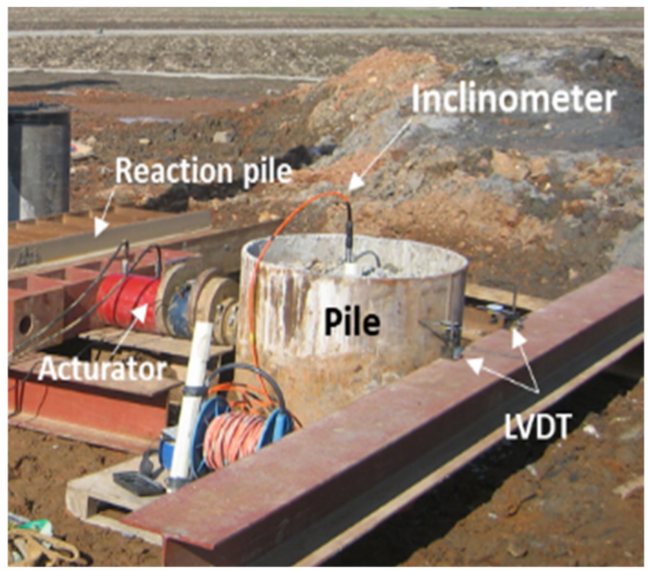

(b)

Figure 6. Field pile load tests: (a) axial pile load testing; (b) Lateral pile load testing.

\subsection{Lateral Pile Load Tests}

Three piles with diameter of $500 \mathrm{~mm}$ (type-1) and four $1000 \mathrm{~mm}$ (type-2) diameter piles were installed on the ground at two different locations in order to perform the static and cyclic lateral pile load tests. The lateral pile load tests were performed with five composite piles, which had different lengths of upper steel pipe pile and lower pre-stressed concrete pile (Figure 6b).

The type- 1 composite pile had an upper steel pipe pile with $500 \mathrm{~mm}$ diameter and $12 \mathrm{~mm}$ thickness and a lower pre-tensioned concrete pile with a $500 \mathrm{~mm}$ diameter and $80 \mathrm{~mm}$ thickness. The type-2 pile consisted of an upper steel pipe pile with a $1000 \mathrm{~mm}$ diameter and a $16 \mathrm{~mm}$, thickness and a lower pre-tensioned concrete pile with $1000 \mathrm{~mm}$ diameter and $130 \mathrm{~mm}$ thickness. The upper and lower parts for both types were connected 
by the non-welded pile connecting method. Table 4 presents different geometries and the length ratio of the upper steel pile for the composite pile with diameters of $500 \mathrm{~mm}$ and $1000 \mathrm{~mm}$.

The load was applied at the center of the pile and the lateral deformations was measured at the top with an LVDT and inclinometer. Three dial gauges with magnetic holders on the test pile and reference piles were used to observe the lateral displacement at the pile head. The lateral displacement along the pile foundations was measured by the inclinometer installed at the center of the pile inside.

The lateral load was applied in increments of around $10 \%$ of the estimated maximum bearing capacity. Each load step was kept constant for $10 \mathrm{~min}$ before applying the next one. Unloading was performed in 10 steps to zero and loaded back to $100 \mathrm{kN}$ again in 10 steps. Maximum loads were applied to $250 \%$ of the design loads or to pile failure, which were $300 \mathrm{kN}$ for type- 1 and $700 \mathrm{kN}$ for type-2, respectively.

\section{Results of Pile Load Tests}

\subsection{Axial Pile Load Tests}

As Pile- 4 and Pile- 5 were installed by augering, pile-driving was carried out at the final process for dynamic load test using PDA. On the other hand, Pile-7 was pile driven and dynamic load testing was performed during pile construction. Pile driving with a $160 \mathrm{kN}$ hydraulic hammer on a large-sized PHC pile succeeded without any damage. To analyze the difference of bearing capacity according to installation methods, we calculated it for the same depth and energy level. Piles built by the augering provided similar values as those installed by pile driving. The shaft resistance of a pile installed by augering, therefore, seemed to be mobilized sufficiently.

To calculate allowable bearing capacity through dynamic pile load tests, Davisson's method [17], which has a traditional safety factor of 2.0, was used to determine the yield limit of the total bearing capacity obtained from Control and Provisioning of Wireless Access Points (CAPWAP) analysis [18] However, in this case, the method used a safety factor of 2.5 [19]. Pile-4 and Pile-5, installed by the augering method, were bored into the bottom of weathered soil layer and had allowable bearing capacity of 1620-3061 kN. However, Pile-7 was driven and socketed into the weathered rock, and had a calculated maximum allowable bearing capacity of $5660 \mathrm{kN}$. The result of the allowable bearing capacities from the dynamic pile load tests is summarized in Table 5.

Table 5. Allowable bearing capacities through dynamic pile load tests.

\begin{tabular}{|c|c|c|c|c|c|c|c|c|}
\hline \multirow[b]{2}{*}{ Pile No. } & \multirow[b]{2}{*}{ Pile Type } & \multirow[b]{2}{*}{$\begin{array}{l}\text { Embedded } \\
\text { Depth } \\
\text { (GL-m) }\end{array}$} & \multirow[b]{2}{*}{$\begin{array}{l}\text { Hammer } \\
\text { Stroke (m) }\end{array}$} & \multirow[b]{2}{*}{$\begin{array}{l}\text { Skin Friction } \\
(\mathbf{k N})\end{array}$} & \multicolumn{2}{|r|}{ Output Values } & \multicolumn{2}{|c|}{ Allowable Bearing Capacity } \\
\hline & & & & & $\begin{array}{l}\text { End Bearing } \\
\text { Capacity }(\mathbf{k N})\end{array}$ & $\begin{array}{l}\text { Total Bearing } \\
\text { Capacity }(\mathbf{k N})\end{array}$ & $\begin{array}{c}\text { Allowable I } \\
\text { CAPWAP } \\
(\mathrm{S} . \mathrm{F}=\mathbf{2 . 5})\end{array}$ & $\begin{array}{l}\text { ng Capacity } \\
\text { Davisson } \\
(\mathrm{S} . \mathrm{F}=2.0)\end{array}$ \\
\hline \multirow{3}{*}{ Pile-4 } & \multirow{3}{*}{$\begin{array}{c}\text { Upper steel pile } \\
(\mathrm{D} 1000,16 \mathrm{t}, 8 \mathrm{~m})+ \\
\text { Lower PHC } \\
(\mathrm{D} 1000,130 \mathrm{t}, 25 \mathrm{~m})\end{array}$} & 32.0 & 0.7 & 1040 & 3410 & 4450 & 1780 & 2225 \\
\hline & & 33.0 & 2.0 & 2902 & 3220 & 6122 & 2449 & 3061 \\
\hline & & & 1.0 & 800 & 3170 & 4050 & 1620 & 2025 \\
\hline \multirow{6}{*}{ Pile-5 } & \multirow{6}{*}{$\begin{array}{l}\text { PHC (D1000, } 130 \mathrm{t}, \\
30 \mathrm{~m})\end{array}$} & 27.5 & 1.5 & 900 & 3630 & 4530 & 1812 & 2265 \\
\hline & & & 0.7 & 900 & 3270 & 4170 & 1660 & 2085 \\
\hline & & 28.5 & 1.0 & 970 & 3560 & 4530 & 1812 & 2265 \\
\hline & & & 0.5 & 910 & 3639 & 4549 & 1820 & 2275 \\
\hline & & 29.0 & 1.0 & 1010 & 4190 & 5200 & 2080 & 2660 \\
\hline & & & 1.5 & 1120 & 4980 & 6100 & 2440 & 3050 \\
\hline \multirow{6}{*}{ Pile-7 } & \multirow{6}{*}{$\begin{array}{c}\text { PHC (D1000, } 130 \mathrm{t} \\
47 \mathrm{~m})\end{array}$} & & 0.5 & 670 & 3260 & 3930 & 1572 & 1965 \\
\hline & & 32.5 & 1.0 & 730 & 3460 & 4190 & 1676 & 2095 \\
\hline & & & 1.5 & 780 & 3700 & 4480 & 1792 & 2240 \\
\hline & & & 0.7 & 4390 & 5270 & 9660 & 3864 & 4830 \\
\hline & & 37.5 & 1.0 & 4560 & 5960 & 10,520 & 4208 & 5260 \\
\hline & & & 1.5 & 4890 & 6430 & 11,320 & 4528 & 5660 \\
\hline
\end{tabular}

A static pile load test on Pile-6 was performed to (1) assess allowable bearing capacity of a large-sized composite pile, (2) confirm the safety of the mechanical joint connecting the upper steel pipe pile and lower PHC pile, (3) verify the results of dynamic pile load tests, and (4) calculate the reliable bearing capacity through a comparative analysis of the 
results of both tests. For the static pile load test, a large-sized composite pile was drilled and socketed into $6.0 \mathrm{~m}$ of weathered rock by using the augering. We planned to load up to $300 \%$ of the expected design load, and repeatedly loaded $12,000 \mathrm{kN}$ in 4 cycles. For enough reaction during the loading process of the load tests, we constructed a reaction system of 16 earth anchors each with a design reaction of $800 \mathrm{kN}$.

Results from the static pile load test demonstrated a total settlement of $24.2 \mathrm{~mm}$ at a maximum load of $12,000 \mathrm{kN}$, residual settlement of $2.1 \mathrm{~mm}$, and elastic recovery of $22.1 \mathrm{~mm}$. According to the results from the yield or ultimate limit analysis and Davisson's analysis [20], the yield limit may be larger than the maximum test load. Therefore, the allowable bearing capacity of the test pile amounted to $6,000 \mathrm{kN}$ or more if the safety rate of 2.0 is applied. The load-displacement responses from dynamic and static axial pile load tests are presented in Figure 7.

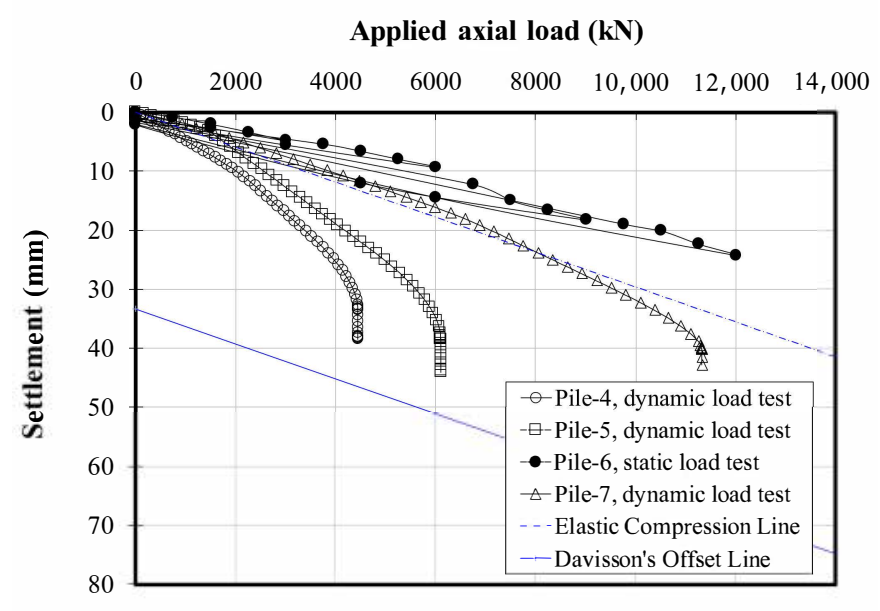

Figure 7. Bearing capacities of static vs. dynamic pile load tests.

\subsection{Lateral Pile Load Tests}

The results of pile load tests showed that the load-deformation responses were different depending on the diameter and length of the upper steel tube piles. Figure 8 shows the lateral displacement with depths for Pile- 4 and Pile- 5 from the inclinometer measurement. Based on this result, Figure 9 presents the relation between load and lateral displacement for type-1 (Figure 9a) and type-2 (Figure 9b) composite pile foundations. For the type-1 foundation at a $100 \mathrm{kN}$ lateral load, the lateral displacements of Pile-1, Pile-2 and Pile-3 were 8.2, 5.2 and $4.3 \mathrm{~mm}$ respectively. At the maximum load of $300 \mathrm{kN}$, the lateral displacements were $21-40 \mathrm{~mm}$; residual displacements were $5.7-26.7 \mathrm{~mm}$. Based on the design criteria in Korea [20], the lateral displacement was limited to $15 \mathrm{~mm}$ ( $3 \%$ of pile diameter), which led to the lateral load capacity of 162, 180 and 235 kN for Pile-1, Pile-2 and Pile-3, respectively. The load capacity, evaluated as the allowable lateral bearing capacity of the composite pile, was larger than the design lateral bearing capacity of $120 \mathrm{kN}$ of the $500 \mathrm{~mm}$ diameter steel pile. 
Lateral displacement(mm)

Pile - 4 (SiteB)

$\begin{array}{llllllllll}-20 & 0 & 20 & 40 & 60 & 80 & 100 & 120 & 140 & 160\end{array}$

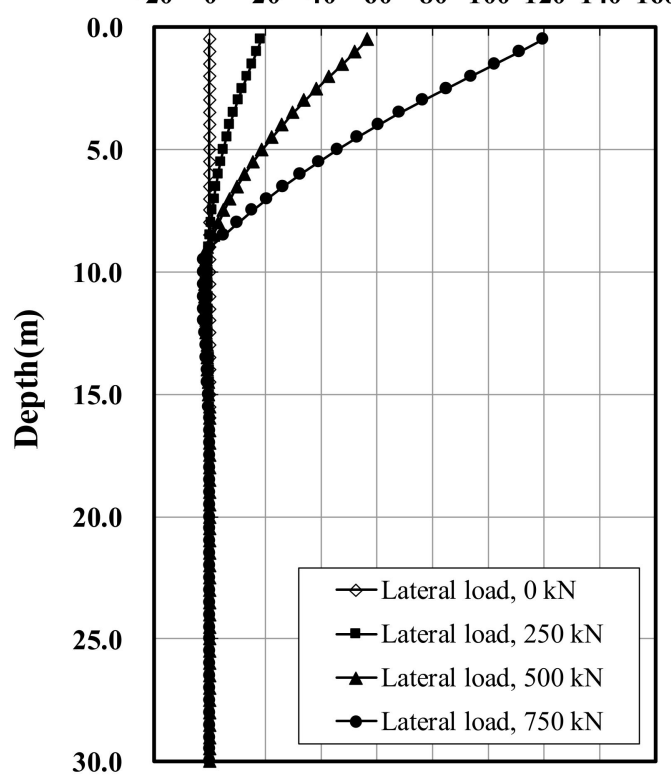

(a)

\section{Lateral displacement(mm)}

Pile - 5 (SiteB)

$\begin{array}{rrrrrrrr}-20 & 0 & 20 & 40 & 60 & 80 & 100120140160\end{array}$

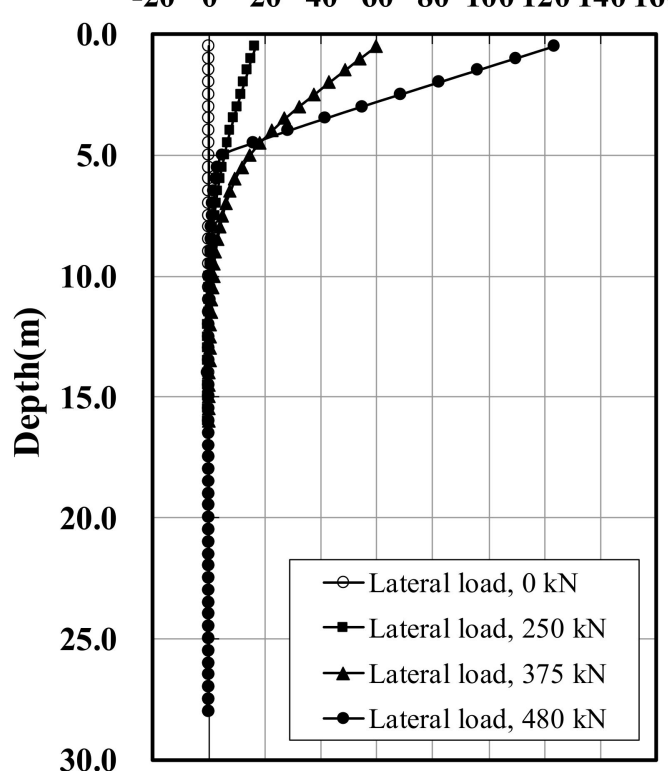

(b)

Figure 8. Lateral displacement with depths: (a) Pile-4; (b) Pile-5.

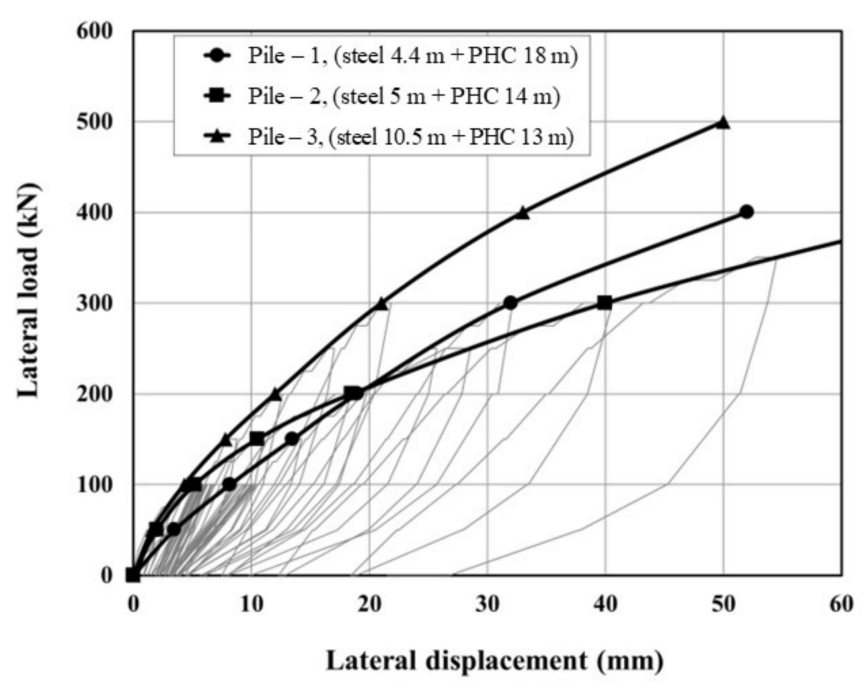

(a)

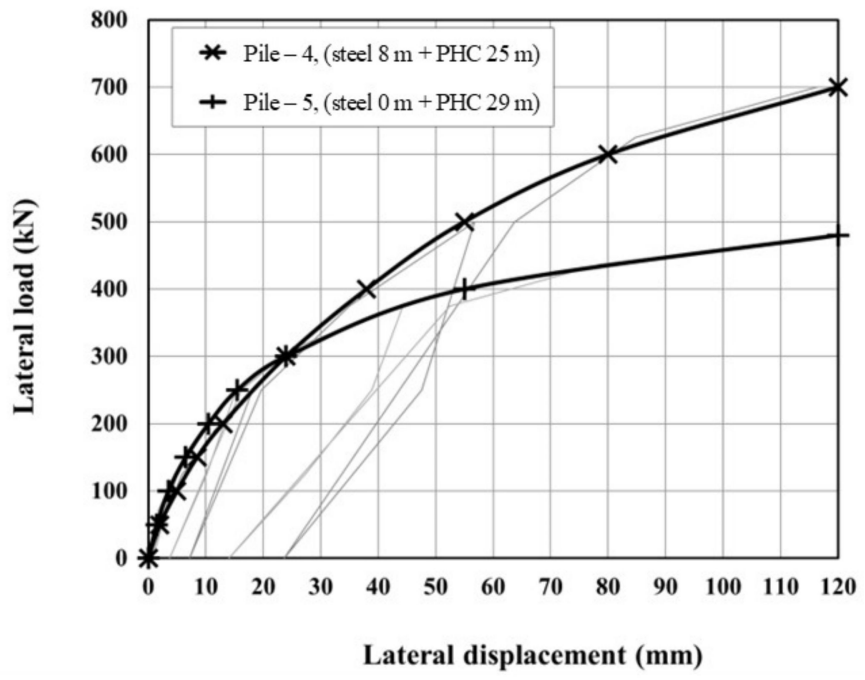

(b)

Figure 9. Load and lateral displacement of field pile load tests for type- 1 and type- 2 composite pile foundations: (a) $500 \mathrm{~mm}$ pile (type-1 for onshore); (b) $1000 \mathrm{~mm}$ pile (type-2 for offshore).

At the maximum load of $700 \mathrm{kN}$ for the type- 2 foundation, the lateral displacements of Pile- 4 were measured at $120 \mathrm{~mm}$. Pile- 5 showed a large displacement at the lateral load of $480 \mathrm{kN}$. The increments of push over load caused the crack behind the pile. The lateral displacement of $30 \mathrm{~mm}$ led to the lateral load capacity of $345 \mathrm{kN}$ and $325 \mathrm{kN}$ for Pile- 4 and Pile-5, respectively. The load capacity evaluated as the allowable lateral bearing capacity of the composite pile was larger than the design lateral bearing capacity of $280 \mathrm{kN}$ of the $1000 \mathrm{~mm}$ diameter steel pile.

The lateral pile load tests showed that the longer the upper steel pile length, the less the lateral pile displacements. It indicated that the location of the pile connection joint between the upper steel piles and lower concrete piles affected the lateral pile behavior. 
However, a length of upper steel pile longer than around $40 \%$ of total pile length hardly affected the lateral behavior.

\section{Interpretation of Test Results}

\subsection{Axial Pile Load Tests}

According to comparative analysis on the results from static and dynamic pile load tests, we found similarities in the load displacement curves of the dynamic pile load test on Pile-7 and static pile load test on Pile- 6 as the bearing layer depth was identical (GL-38.0 m) in both tests. We also learned that the size of bearing capacity was larger in the static test than in the dynamic test. This was attributable to the lack of setup effects over time in the dynamic pile load test. If the setup effects were taken into consideration, the bearing capacity of the dynamic pile load test would have been almost the same as that of the static test.

\subsection{Lateral Pile Load Tests}

One of the frequently used methods for the design of lateral loaded pile foundations is the beam spring approach using $p-y$ curves recommended by API RP 2A [21]. The $p-y$ curve recommended by API RP 2A was derived from field tests carried out at the Sabine River in the U.S. The tests included static and cyclic loading of a diameter of $0.324 \mathrm{~m}$ tubular steel pile driven to $12.8 \mathrm{~m}$ tip depth in a slightly over-consolidated marine clay. Another $p-y$ curve proposed by Jeanjean [22] was based on the cyclic centrifuge test results presenting a formula for the reduction in the $p-y$ secant modulus as a function of the number of load cycles. The formula used to calculate the ultimate lateral capacity and the static $p-\mathrm{y}$ curves are shown below.

$$
\frac{P}{P_{\max }}=\tanh \left[\frac{G_{\max }}{100 \cdot S_{u}} \cdot\left(\frac{y}{D}\right)^{0.5}\right]
$$

where, $P_{\max }$ is $N_{p} S_{u}$; $G_{\max }$ is the maximum shear modulus; $S_{u}$ is the shear strength; $y$ is the lateral displacement, $D$ is pile diameter. Here, $N_{p}=12-4 \mathrm{e}^{(-\xi z / D)} ; \xi=0.25+0.05 \lambda$ (for $\lambda<6$ ) or $\xi=0.55$ (for $\lambda \geq 6$ ); $\lambda=\left(S_{u 0}\right) /\left(S_{u 1} D\right) ; S_{u 0}$ is the shear strength intercept on the seafloor; $S_{u 1}$ is the rate of increase of shear strength with depth; $z$ is the depth of interest.

For this study, two different $p-y$ models proposed by API RP 2A [21] and Jeanjean [22] with different $G_{\max } / s_{u}$ were selected to compare the load-deformation to the field pile load tests. Figure 10 presents the results of the field lateral pile load tests and beamspring analyses. The lateral pile displacements at the ground from the pile load tests were compared to the results of beam-spring analyses by using different $p-y$ curves.

Figure 10 illustrates the static and cyclic load-displacement response based on the field pile load tests. Unloading and reloading were performed in 10 steps to zero and loaded back to $100 \mathrm{kN}$ again in 10 steps in order to obtain the cyclic load-displacement response shown in Figure $10 \mathrm{a}-\mathrm{c}$. It is obvious that there was a residual lateral displacement under the cyclic loadings at the field load tests.

The comparison of load-displacement responses showed that the recommendation of API RP 2A generally over-estimated the lateral displacement with moduli and ultimate load to a lesser degree than the data from field pile load tests. For type- 1 with $500 \mathrm{~mm}$-diameter composite piles, Figure 10a-c compares the field test results to the load-displacement curve calculated by API RP 2 A and the Jeanjean model with a $G_{\max } / s_{u}$ value of 400 and 600 . It can be seen that reasonably good agreement was obtained between the field test results and Jeanjean model with $G_{\max } / s_{u}=400$. 

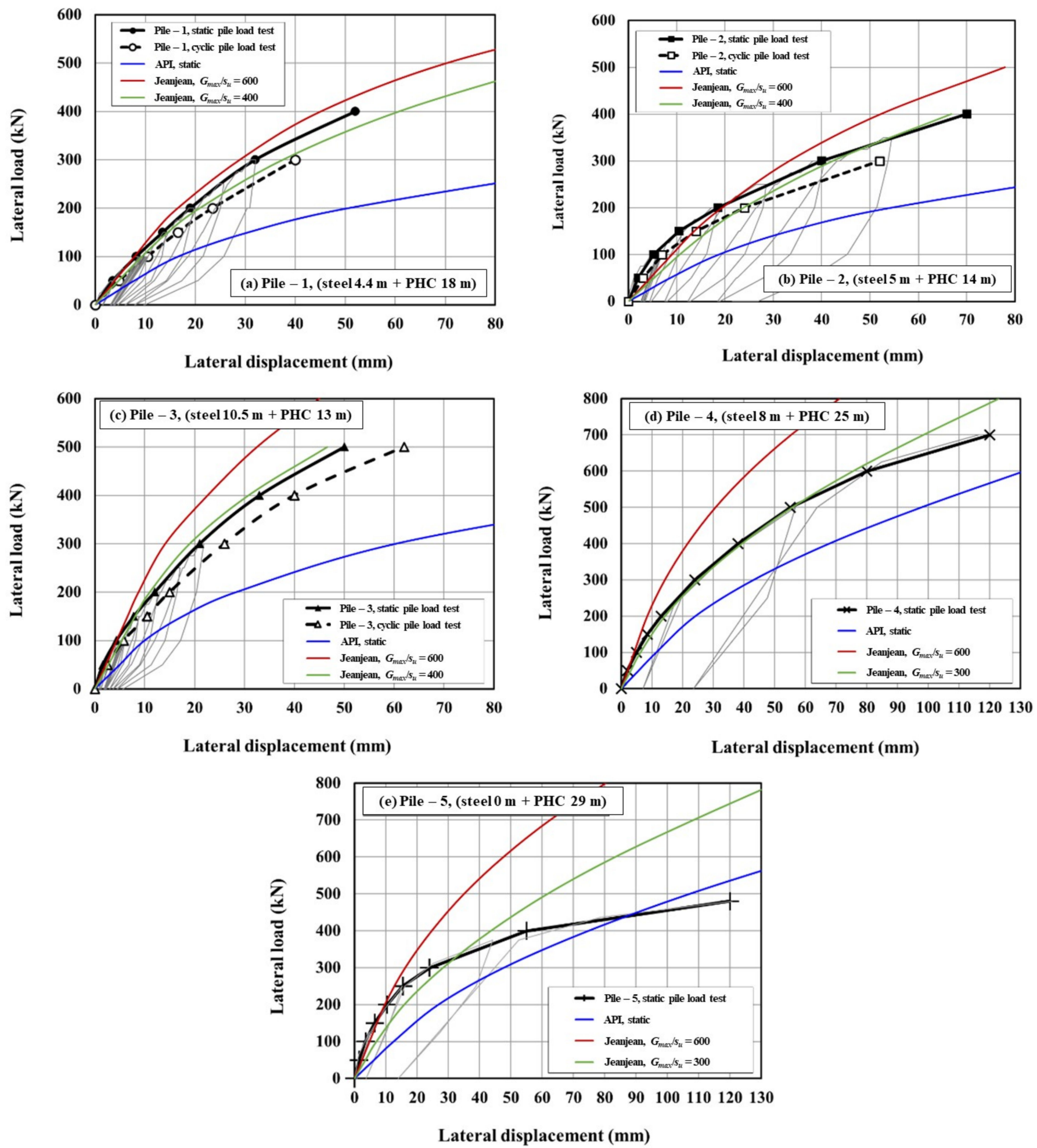

Figure 10. Load and lateral displacement of field pile load tests and beam-spring analysis for composite piles of type-1 and type-2 : (a) Pile-1, (steel $4.4 \mathrm{~m}$ + PHC $18 \mathrm{~m}$ ); (b) Pile-2, (steel $5 \mathrm{~m}$ + PHC $14 \mathrm{~m}$ ); (c) Pile-3, (steel $10.5 \mathrm{~m}+$ PHC 13 m); (d) Pile-4, (steel $8 \mathrm{~m}+$ PHC 25 m); (e) Pile-5, (steel $0 \mathrm{~m}+$ PHC 29 m).

Figure 10d,e compares the field test results of the large diameter composite piles and the load-displacement curve calculated by API RP 2A and the Jeanjean models. For Pile-4, the load-displacement curve from the field load tests and the calculated result by the Jeanjean model with $G_{\max } / s_{u}=300$ showed very good agreement in the initial moduli. 
For Pile-5, the load-displacement curve from the field load test showed stiff initial moduli and low ultimate capacity due to a crack behind of the concrete pile over the lateral load of $400 \mathrm{kN}$.

Figure 11 indicates the normalized lateral load, $p / p_{\max }$ versus the normalized later displacement, $y / D$, compared to the $p-y$ curve recommended by API RP $2 \mathrm{~A}$ and the Jeanjean model for a composite pile with diameters of 500 and $1000 \mathrm{~mm}$.

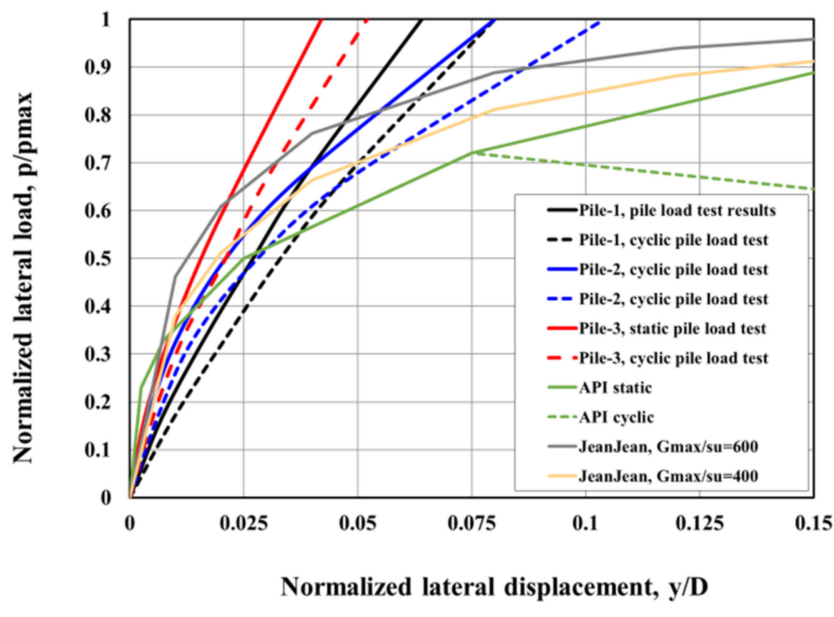

(a)

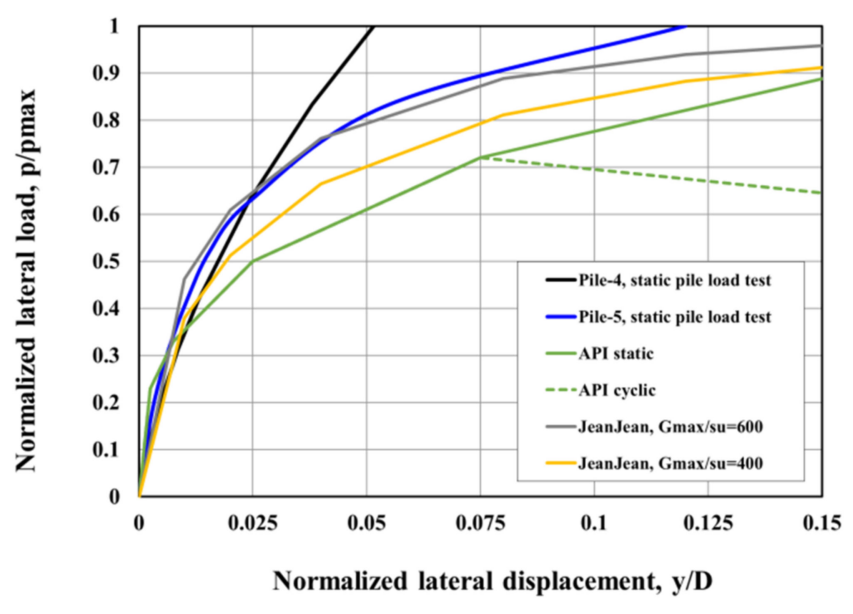

(b)

Figure 11. Load and lateral displacement of field pile load tests and beam-spring analysis for composite piles of type-1 and type-2: (a) $500 \mathrm{~mm}$ pile (type-1 for onshore); (b) $1000 \mathrm{~mm}$ pile (type-2 for offshore).

Generally, the load-displacement response from the field pile load tests showed good agreement with the result by the proposed Jeanjean model for the composite pile with a $500 \mathrm{~mm}$ diameter. For the large composite pile for the purposes of offshore foundation, the ultimate pile capacity was noticed to be lower than the capacity calculated by the proposed model. It seemed to be related to the behavior and the integrity of the mechanical joint at the large lateral displacement.

It was seen that the load-displacement response of the $500 \mathrm{~mm}$ composite pile was significantly affected by the length of upper steel pile because the difference of stiffness between it $\left(\mathrm{EI}_{\text {steel }}=115,075 \mathrm{kN} \cdot \mathrm{m}^{2}\right)$ and the lower concrete pile $\left(\mathrm{EI}_{\text {con'c }^{\prime}}=84,385 \mathrm{kN} \cdot \mathrm{m}^{2}\right)$ was relatively high. But if the large composite pile with a diameter of $1000 \mathrm{~mm}$ had enough pile capacity, the effect of the length of the upper steel pile could have been neglected because the difference of pile stiffness between the upper steel piles $\left(\mathrm{EI}_{\text {steel }}=1.25 \times 106 \mathrm{kN} \cdot \mathrm{m}^{2}\right)$ and lower concrete piles $\left(\mathrm{EI}_{\text {con'c }}=1.20 \times 106 \mathrm{kN} \cdot \mathrm{m}^{2}\right)$ was relatively small.

\section{Conclusions}

In this study, the small-sized composite piles (steel pile + pre-tensioned high strength concrete pile, PHC) having a diameter of $500 \mathrm{~mm}$ were investigated by field pile load tests. The applicability of large-sized composite piles and PHC piles with a diameter of $1000 \mathrm{~mm}$ was comprehensively evaluated to determine its potential use in offshore wind foundations. We installed piles by augering (Pile-4, 5, and 6) and the driving method (Pile-1, 2, 3, and 7). Through the dynamic axial pile load tests and a static axial pile load test, we analyzed the drivability of the composite piles and evaluated allowable bearing capacities. Site investigations were carried out at the two test sites (site-A and site-B). The results are summarized as follows:

From the axial dynamic and static pile load tests, the drivability of the composite pile was verified without any damage to the piles or the connection joint. It was found that piles installed by augering presented similar axial bearing capacity to piles driven by hammer. Piles penetrated to the weathering soil (Piles-4,5) showed an allowable bearing capacity of $3061 \mathrm{kN}$. Piles socketed into the weathered rocks (Pile-7) showed a maximum allowable 
bearing capacity of approximately $5660 \mathrm{kN}$. According to results from the static pile load test, the total settlement reached nearly $24.2 \mathrm{~mm}$ with a maximum load of $12,000 \mathrm{kN}$, residual settlement $2.1 \mathrm{~mm}$, and elastic recovery $22.1 \mathrm{~mm}$. The allowable bearing capacity was calculated to be over $6000 \mathrm{kN}$ if the safety rate of 2.0 was applied.

From the lateral pile load tests, the load-displacement responses of composite pile were observed by field pile load tests and were compared to the results from beam-spring analysis. Based on those results, the site-specific load-displacement curve ( $p-y$ curve) was proposed and pile integrity was investigated with a practical design approach. The results of pile load tests were compared to the results of beam-spring analyses by an API RP $2 \mathrm{~A}$ recommendation and the Jeanjean model. Results showed that the load-displacement response recommended by API RP $2 \mathrm{~A}$ can be more conservative with initial stiffness and ultimate load than the pile load test results. Site specific backbone curves by using the Jeanjean model was suggested and the integrity of the pile connection was verified.

Author Contributions: Conceptualization, Y.S.; methodology, Y.S., T.L. and K.C.; formal analysis: Y.S. and J.K.; investigation, T.L. and J.P.; data curation, Y.S. and J.K.; writing-original draft preparation, Y.S. and J.K.; review and editing, Y.S. and J.K. All authors have read and agreed to the published version of the manuscript.

Funding: This work was supported by research fund of Chungnam National University and the Korea Institute of Energy Technology Evaluation and Planning (KETEP), granted financial resource from the Ministry of Trade, Industry \& Energy, Republic of Korea (No. 2012T100201671). In addition, this work was supported by the National Research Foundation of Korea (NRF) grant funded by the Korea government (MSIT) (No. 2020R1F1A1076193).

Institutional Review Board Statement: Not applicable.

Informed Consent Statement: Not applicable.

Data Availability Statement: Not applicable.

Acknowledgments: The authors would like to acknowledge the help of many colleagues to help with this study. We are particularly grateful to GS E\&C for the effort of researching together on the pile-soil interaction of offshore wind hybrid substructure systems.

Conflicts of Interest: The authors declare no conflict of interest.

\section{References}

1. Burd, H.J.; Byrne, B.W.; McAdam, R.A.; Houlsby, G.T.; Martin, C.M.; Beuckelaers, W.J.A.P.; Zdravkovic, L.; Taborda, D.M.G.; Potts, D.M.; Jardine, R.J.; et al. Design Aspects for Monopile Foundations. In Proceedings of the TC 209 Workshop 19th ICSMGE, Seoul, Korea, 20 September 2017; pp. 35-44.

2. Bhattacharya, S. Challenges in Design of Foundations for Offshore Wind Turbines. Eng. Technol. Ref. 2014, 1, 922. [CrossRef]

3. Koh, J.H.; Ng, E.Y.K. Downwind Offshore Wind Turbines: Opportunities, Trends and Technical Challenges. Renew. Sustain. Energy Rev. 2016, 54, 797-808. [CrossRef]

4. Willis, D.J.; Niezrecki, C.; Kuchma, D.; Hines, E.; Arwade, S.R.; Barthelmie, R.J.; Dipaola, M.; Drane, P.J.; Hansen, C.J.; Inalpolat, M.; et al. Wind Energy Research: State-of-the-Art and Future Research Directions Simulator for Wind Farm Applications. Renew. Energy 2018, 125, 133-154. [CrossRef]

5. Oh, K.; Nam, W.; Sung, M.; Kim, J.; Epureanu, B.I. A Review of Foundations of Offshore Wind Energy Convertors: Current Status and Future Perspectives. Renew. Sustain. Energy Rev. 2018, 88, 16-36. [CrossRef]

6. Wang, X.; Zeng, X.; Li, J.; Yang, X.; Wang, H. A Review on Recent Advancements of Substructures for Offshore Wind Turbines. Energy Convers. Manag. 2018, 158, 103-119. [CrossRef]

7. Mathern, A.; Von der Haar, C.; Marx, S. Concrete Support Structures for Offshore Wind Turbines: Current Status, Challenges, and Future Trends. Energies 2021, 14, 1995. [CrossRef]

8. Fellenius, B.; Kim, S.; Chung, S. Long-Term Monitoring of Strain in Instrumented Piles. J. Geotech. Geoenviron. Eng. 2009, 135, 1583-1595. [CrossRef]

9. Shin, Y.; Kim, M.; Ko, J.; Jeong, S. Proposed Design Chart of Mechanical Joints on Steel-PHC Composite Piles. Mater. Struct. 2014, 47, 1221-1238. [CrossRef]

10. Korea Institute of Energy Technology Evaluation and Planning. Development of Hybrid Substructure Systems for Offshore Wind Power; Korea Institute of Energy Technology Evaluation and Planning: Seoul, Korea, 2013. 
11. Haiderali, A.E.; Madabhushi, S.P.G. Enhancing the Lateral Capacity of Monopiles in Sand using Reinforced Concrete Footings. In Proceedings of the XVI ECSMGE Geotechnical Engineering for Infrastructure and Development; ICE Publishing: London, UK, 2015; ISBN 978-0-7277-6067-8. [CrossRef]

12. Kim, H.G.; Kim, B.J.; Lee, K. Analysis of Piled Concrete Foundation for a 3-MW Class Offshore Wind Turbine along the Southwest Coast in Korea. J. Mar. Sci. Eng. 2020, 8, 215. [CrossRef]

13. Matlock, H. Correlations for Design of Laterally Loaded Piles in Soft Clay. In Proceedings of the 2nd Offshore Technology Conference, Houston, TX, USA, 22-24 April 1970; pp. 577-597.

14. Poulos, H.G. Behavior of Laterally Loaded Piles: I-Single Piles. J. Soil Mech. Found. Div. 1971, 97, 711-731. [CrossRef]

15. Reese, L.C. Laterally Loaded Piles: Program Documentation. J. Geotech. Eng. Div. 1977, 103, 287-305. [CrossRef]

16. American Society for Testing and Materials. ASTM D1143/D1143M-20, Standard Test Methods for Deep Foundation Elements Under Static Axial Compressive Load; ASTM International: West Conshohocken, PA, USA, 2020.

17. Davisson, M. High Capacity Piles. In Proceedings, Soil Mechanics Lecture Series on Innovations in Foundation Construction; ASCE, Illinois Section: Chicago, IL, USA, 1972.

18. Iskander, M.G.; Stachula, A. Wave Equation Analyses of Fiber-Reinforced Polymer Composite Piling. J. Compos. Constr. 2002, 6, 88-96. [CrossRef]

19. Korean Geotechnical Society (KGS). Design Standards for Foundation Structures; Ministry of Land, Transport and Maritime Affairs: Seoul, Korea, 2008.

20. Ministry of Land, Transport and Maritime Affairs. Bridge Design Specifications (in Korean); Ministry of Land, Transport and Maritime Affairs: Gwacheon, Korea, 2008.

21. American Petroleum Institute. Recommended Practice for Planning, Designing and Constructing Fixed Offshore Platforms-Working Stress Design. RP 2A-WSD; American Petroleum Institute: Washington, DC, USA, 2010.

22. Jeanjean, P. Re-Assessment of P-Y Curves for Soft Clay from Centrifuge Testing and Finite Element Modeling. In Proceedings of the Offshore Technology Conference, Houston, TX, USA, 4-7 May 2009; p. 17861. 